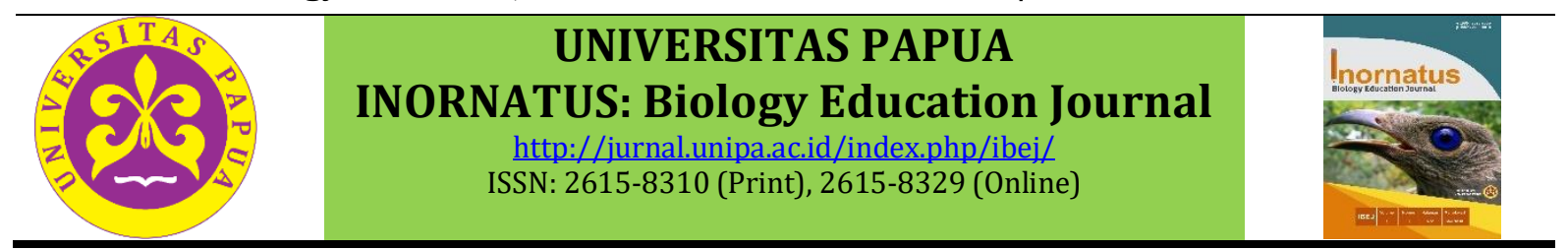

\title{
Project-based learning to create effective biology teaching
}

\section{Pembelajaran berbasis proyek untuk menciptakan pengajaran biologi yang efektif}

\author{
Caesilia Somi Beluan, Idola Dian Yoku Nebore, Jeni Jeni* \\ 1Universitas Papua, Indonesia \\ *korespondensi penulis : j.jeni@unipa.ac.id
}

\begin{abstract}
This research aims to create effective biology teaching to improve student learning outcomes and activeness using project-based learning (PjBL). Classroom action research (CAR) was used to create effective learning. A total of 24 students became the subject of this CAR. They are in class XI IPA. Students were observed for three meetings using the observation sheet to measure attitudes, skills, and activity. We were measuring students' cognitive learning outcomes using tests. The CAR results showed that $79.16 \%$ of students achieved a minimum standard of 70 . A total of $66.67 \%$ achieved skills from good to very good. Student activity and teacher activity has increased. This CAR concludes that PjBL effectively improves biology learning and improves students' learning outcomes. Some students have not reached the good category, so further research in the use of PjBL can be improved.
\end{abstract}

Keywords: Biology, activeness, skills, project-based learning, attitude

\section{Abstrak}

Riset ini bertujuan menciptakan pengajaran biologi yang efektif untuk memperbaiki hasil belajar dan keatifan siswa menggunakan pembelajaran berbasis proyek atau disebut PjBL. Penelitian tindakan kelas (PTK) digunakan untuk menciptakan pembelajaran efektif. Sebanyak 24 siswa menjadi subjek dari PTK ini. Mereka berada pada kelas XI IPA. Siswa diobservasi selama tiga kali pertemuan dengan menggunakan lembar observasi untuk mengukur sikap, keterampilan, dan keaktifan. Mengukur hasil belajar kognitif siswa menggunakan tes. Hasil PTK memperoleh bahwa 79,16\% siswa mencapai standar minimal 70. Sebanyak 66,67\% mencapai keterampilan dan baik sampai sangat baik. Keaktifan siswa dan aktivitas guru mengalami peningkatan. PTK ini menyimpulkan bahwa PjBL secara efektif meningkatkan pembelajaran biologi dan membuat siswa meningkat hasil belajarnya. Terdapat beberapa siswa belum mencapai kategori baik sehingga riset selanjutnya dalam penggunaan PjBL dapat ditingkatkan.

Kata Kunci: Biologi, keaktifan, keterampilan, pembelajaran berbasis proyek, sikap

\section{Pendahuluan}

Pengajaran yang efektif adalah pengajaran yang mampu menciptakan suasana yang melibatkan siswanya dalam kegiatan aktif. Kemampuan mengajar guru berkaitan dengan tujuan pencapaian pembelajaran sains (Demirdöğen, 2016; Watem, Nunaki, \& Wambrauw, 2018). Menurut Ferguson dan Danielson (2015) bahwa melibatkan siswa dalam proses pemecahan masalah, diskusi, dan bekerja secara aktif adalah contoh bentuk pengajaran efektif. Desain pembelajaran yang inovatif menciptkan pembelajaran yang efektif memperbaiki kognitif dan keterampilan siswa (Damopolii, Yohanita, Nurhidaya, \& Murtijani, 2018). Mendukung dan memfasilitasi pembelajaran dan keterlibatan siswa akan menciptakan efektifnya pembelajaran (Bahtiar, Nunaki, \& Iwan, 2018; O'Neill, Geoghegan, \& Petersen, 2013; Samara, Yohanita, \& Iwan, 2018) 
Hasil wawancara yang dilakukan oleh peneliti terhadap guru mata pelajaran biologi di SMA YPPK St. Arnoldus Yansen Bintuni, menyatakan bahwa terdapat dua rombongan belajar untuk kelas XI IPA dan beberapa masalah yang sering ditemukan di dalam kedua kelas. Masalah terjadi terutama di kelas XI IPA adalah siswa belum berani untuk bertanya dan menyampaikan pendapat sehingga kelas berkesan pasif. Beberapa siswa yang pasif cenderung memiliki hasil belajar yang rendah, hal ini tampak pada hasil belajar peseta didik di bawah kriteria ketuntasan. Laboratorium Biologi telah tersedia, namun peralatan laboratorium dan media pembelajaran yang mendukung pembelajaran biologi masih terbatas. Belajar lebih menyenangkan dalam situasi praktis dan langsung dapat diterapkan pada tugas-tugas tertentu (Allison et al., 2015) dalam bentuk pembelajaran berbasis proyek (PjBL - Project based learning)

Dalam praktik dunia nyata, PjBL adalah metode pengajaran yang berpusat pada pembelajar aktif yang dicirikan oleh otonomi siswa tingkat tinggi, penyelidikan secara konstruktif, penentuan tujuan, saling kolaborasi, terlibat dalam komunikasi, dan refleksi di pihak siswa (Kokotsaki, Menzies, \& Wiggins, 2016). Kemampuan kognitif seperti pemecahan masalah, pemahaman ide dan penggunaanya dalam praktek, serta non kognitif seperti motivasi, kolaborasi, kesadaran lingkungan dan ketekunan muncul saat penerapan PjBL (Kokotsaki et al., 2016). PjBL membantu mendorong pembelajaran mandiri dan dapat mempromosikan pengetahuan konseptual siswa dalam proses sistematis untuk mendokumentasikan dan merefleksikan pembelajaran (Barak, 2012). Keberhasilan penerapan PjBL di kelas terletak pada performa guru untuk secara tepat dan efektif membantu pembelajaran siswanya, memotivasi, mendukung dan membimbing mereka sepanjang jalan (Kokotsaki et al., 2016)

Al-Balushi dan Al-Aamri (2014) melakukan penelitian kuasi-eksperimental dengan 62 siswa perempuan kelas 11 di Oman yang mengeksplorasi pengaruh proyek ilmu lingkungan pada pengetahuan dan sikap lingkungan siswa menuju ilmu pengetahuan. Temuannya positif, dengan kelompok PjBL mengungguli kontrol dalam tes pengetahuan. Para siswa dalam kelas PjBL menggunakan teknologi baru untuk merancang produk mereka dapat menyebabkan hasil yang lebih positif dalam tes akhir. Studi lain menunjukkan motivasi pelajar yang lebih tinggi dalam lingkungan kelas PjBL, dengan sampel siswa berumur 14 dan 15 tahun di Israel menunjukkan minat yang meningkat dalam mempelajari mata pelajaran sains-teknologi (Barak \& Asad, 2012).

\section{Metode}

Riset PTK (penelitian tindakan kelas) dilakukan di XI IPA SMA YPPK St. Arnoldus Yansen, Bintuni. Siswa sebanyak 24 orang menjadi dalam PTK ini (8 laki-laki dan 16 perempuan). Penelitian dilaksanakan hanya sebanyak satu siklus dengan total tiga pertemuan. Sebelum dilakukan tindakan, dilakukan pengukuran awal sebagai data pra siklus.

Perangkat dan instrumen seperti lembar observasi (untuk guru dan keaktifan siswa), RPP (Rencana pelaksanaan pembelajaran), LKPD / lembar kerja siswa, tes hasil belajar divalidasi oleh dua ahli. Hasil penilaian ahli meningdikasikan perangkat dan instrumen dapat digunakan dalam pembelajaran. Selain itu diukur juga sikap dan keterampilan siswa selama penerapan $\mathrm{PjBl}$. Materi pengajaran berfokus pada biologi sel. Siswa dikatakan berhasil (tuntas) jika memperoleh skor $\leq 70$. Ketuntasan kelas ditentukan berdasarkan 75\% siswa yang memperoleh skor $\leq 70$. Kriteria aktivitas guru, keaktifan siswa, sikap dan keterampilan siswa berdasarkan kategori sangat aktif / baik (86 - 100), Aktif / baik (71 - 85), cukup aktif / baik (61 - 70), kurang aktif / baik (51 $60)$, dan sangat kurang aktif / baik $(\leq 50)$. 


\section{Hasil dan Pembahasan}

Hasil penelitian menghadirkan beberapa data seperti hasil validasi ahli dan empirik, normalitas, homogenitas dan hasil uji perbedaan. Berikut disajikan hasil analisis data.

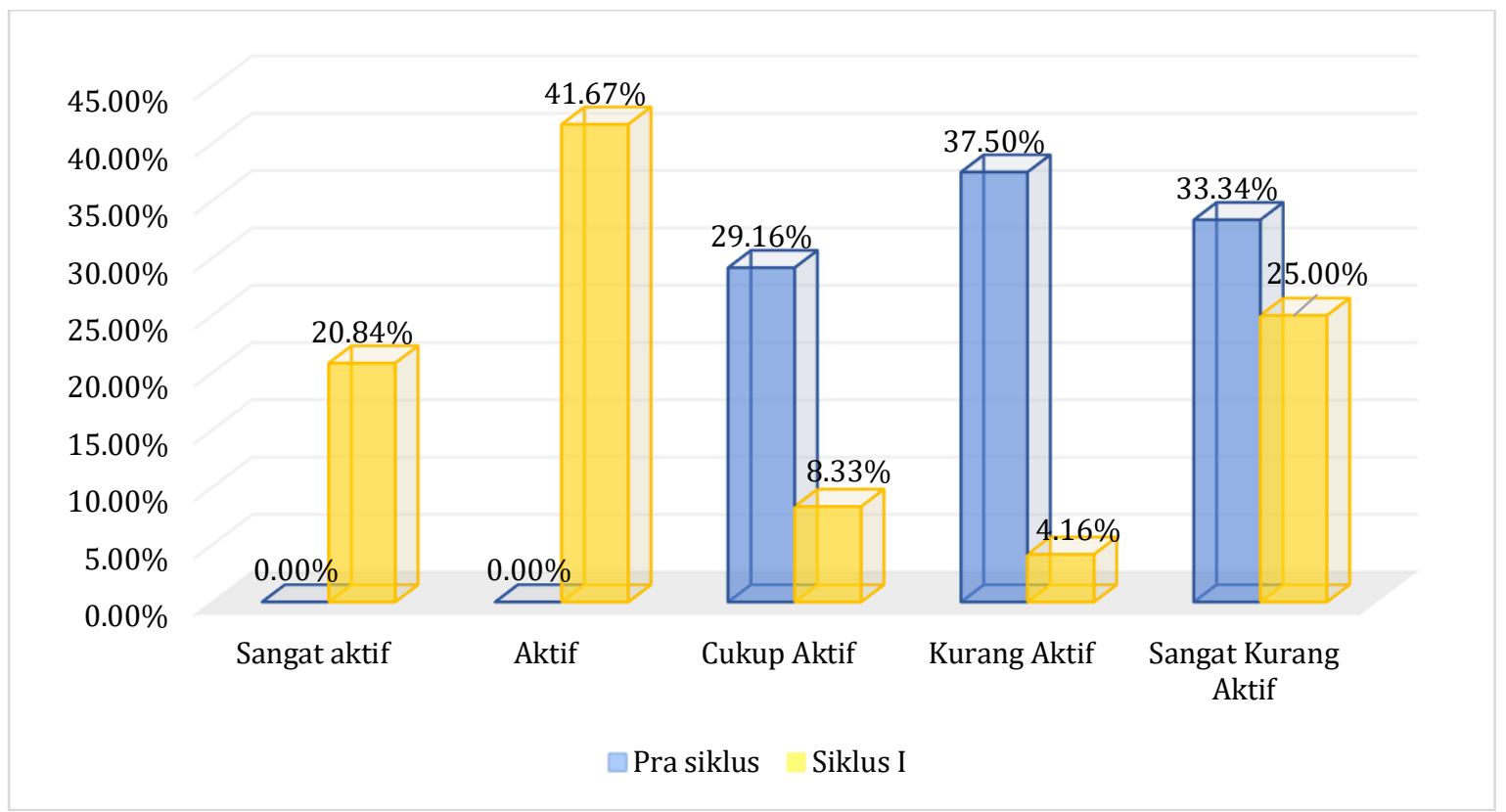

Gambar 1. Keaktifan siswa selama pembelajaran

Berdasarkan data pada Gambar 1 terindikasi bahwa sebelum penerapan PjBL siswa lebih banyak kurang aktif bahkan sangat kurang aktif. Hanya 29,16\% siswa yang aktif. Tidak ditemukan siswa aktif dan sangat aktif. Setelah penggunaan PjBL keaktifan siswa meningkat menjadi $62.51 \%$ pada kriteria aktif dan sangat aktif.

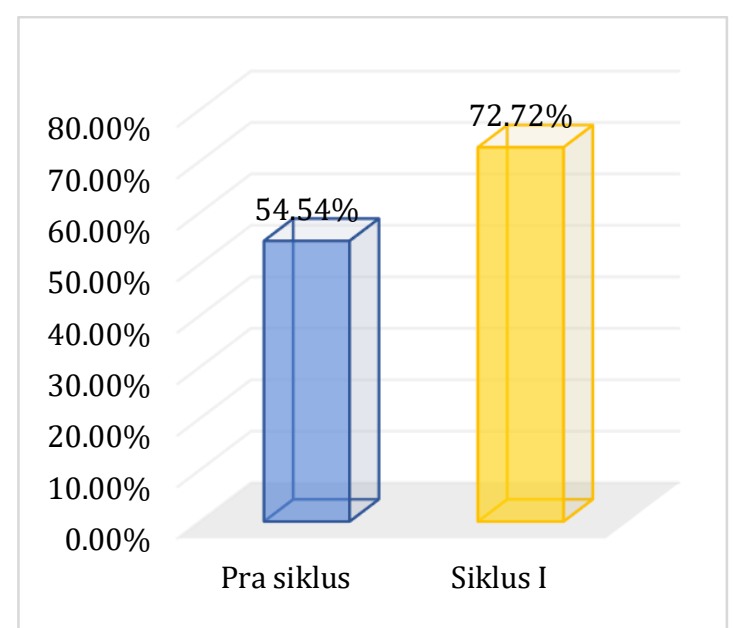

Gambar 2. Aktivitas guru selama pra siklus dan setelah siklus I

Data Gambar 2 menungkap fakta bahwa saat pra siklus (sebelum penerapan PjBL) aktivitas guru adalah kurang. Akibat penggunaan PjBL dalam pembelajaran menyebabkan aktivitas guru meningkat menjadi aktif $(72,72 \%)$. 


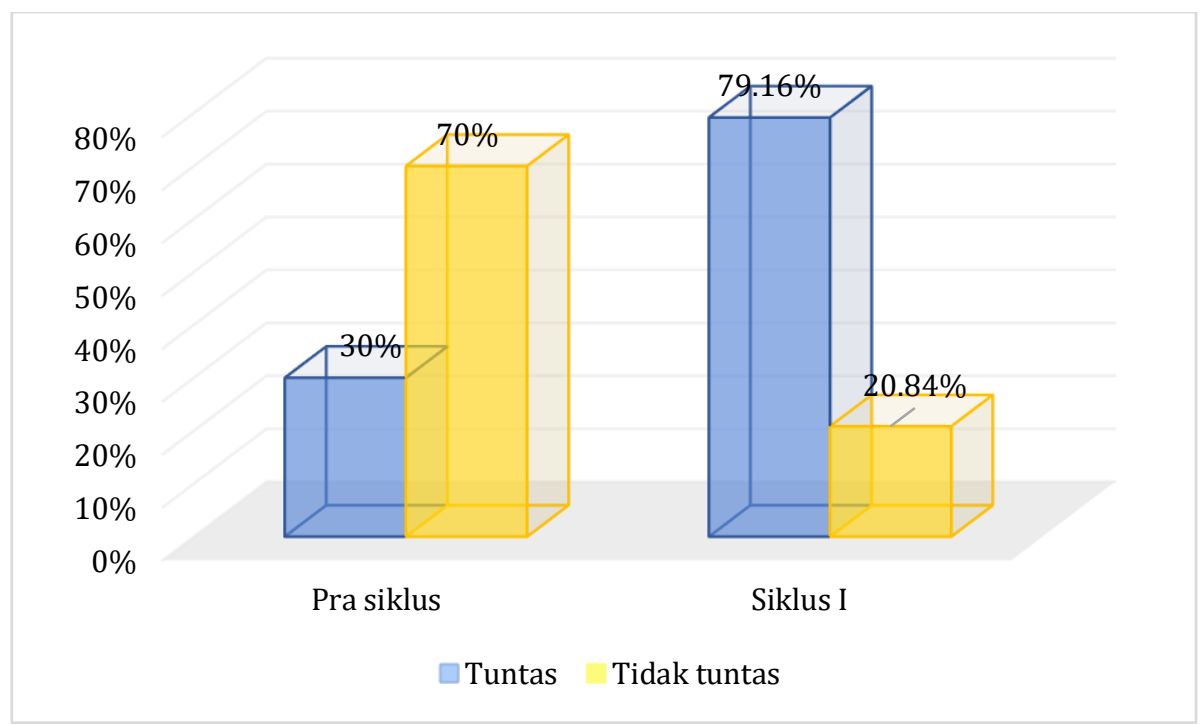

Gambar 3. Capaian belajar kognitif siswa

Data ketuntasan belajar siswa yang ada pada Gambar 3 megindikasikan bahwa hanya 30\% siswa yang tuntas. Sebelum penerapan PjBL terdapat 70\% siswa yang tidak tuntas. Tidak sesuai dengan standar sekolah bahwa 75\% siswa harus mencapai skor 70 . Setelah penerapan PjBL mengungkap fakta bahwa terjadi peningkatan sebesar 49,16\%. Sebanyak 79,16\% siswa telah mencapai ketuntasan minimal belajar.

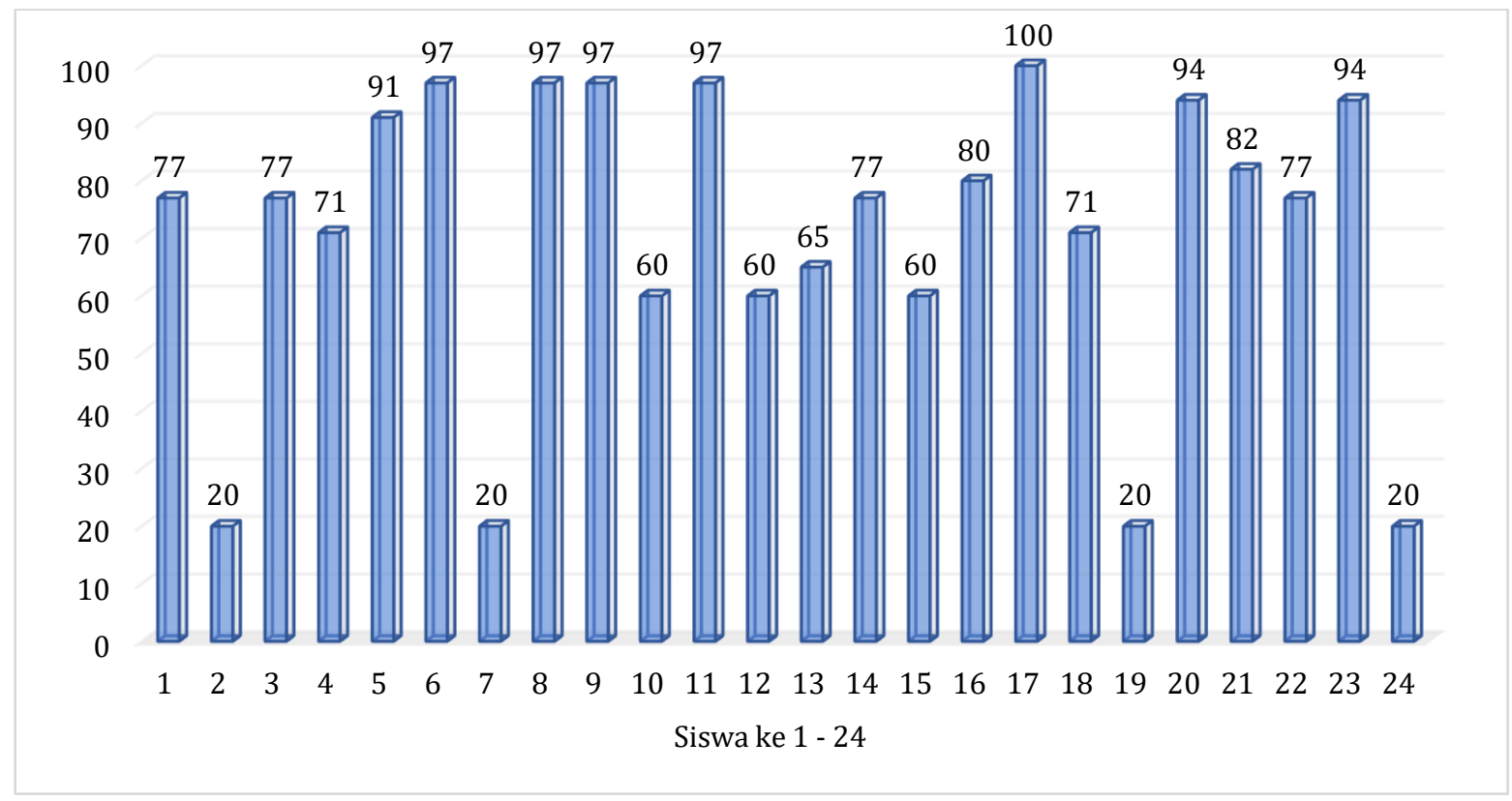

Gambar 4. Hasil pengukuran keterampilan siswa selama PjBL

Gambar 4 mengindikasikan bahwa keterampilan siswa selama penerapan PjBL menunjukkan data yang berbeda. Skor terendah 20 dan tertinggi 100. Masih terdapat 4 $(16,67 \%)$ yang memiliki keterampilan yang sangat kurang baik, bgitu juga yang mendapat skor dengan kriteria cukup baik. Sisanya $66,67 \%$ mencapai kriteria baik dan sangat baik.

Pada gambar 5 menunjukkan data sikap siswa selama penerapan PjBL. Hasil mengindikasikan bahwa $5(20,83 \%)$ siswa yang memiliki sikap yang sangat kurang baik. Begitu juga siswa yang menunjukkan sikap yang kurang baik sebanyak 3 (12.50\%). 
Sisanya sebanyak $66,67 \%$ mencapai kriteria baik dan sangat baik. Jika diperhatikan data pada Gambar 4 dan 5, terungkap bahwa siswa nomor 2, 7, 19 dan 24 menunjukkan keterampilan dan sikap yang kurang. Sementara itu, walalupun siswa nomor 13 menunjukkan sikap yang kurang baik, tetapi keterampilannya masih cukup baik. Hal ini perlu menjadi perhatian untuk perbaikan di riset selanjutnya.

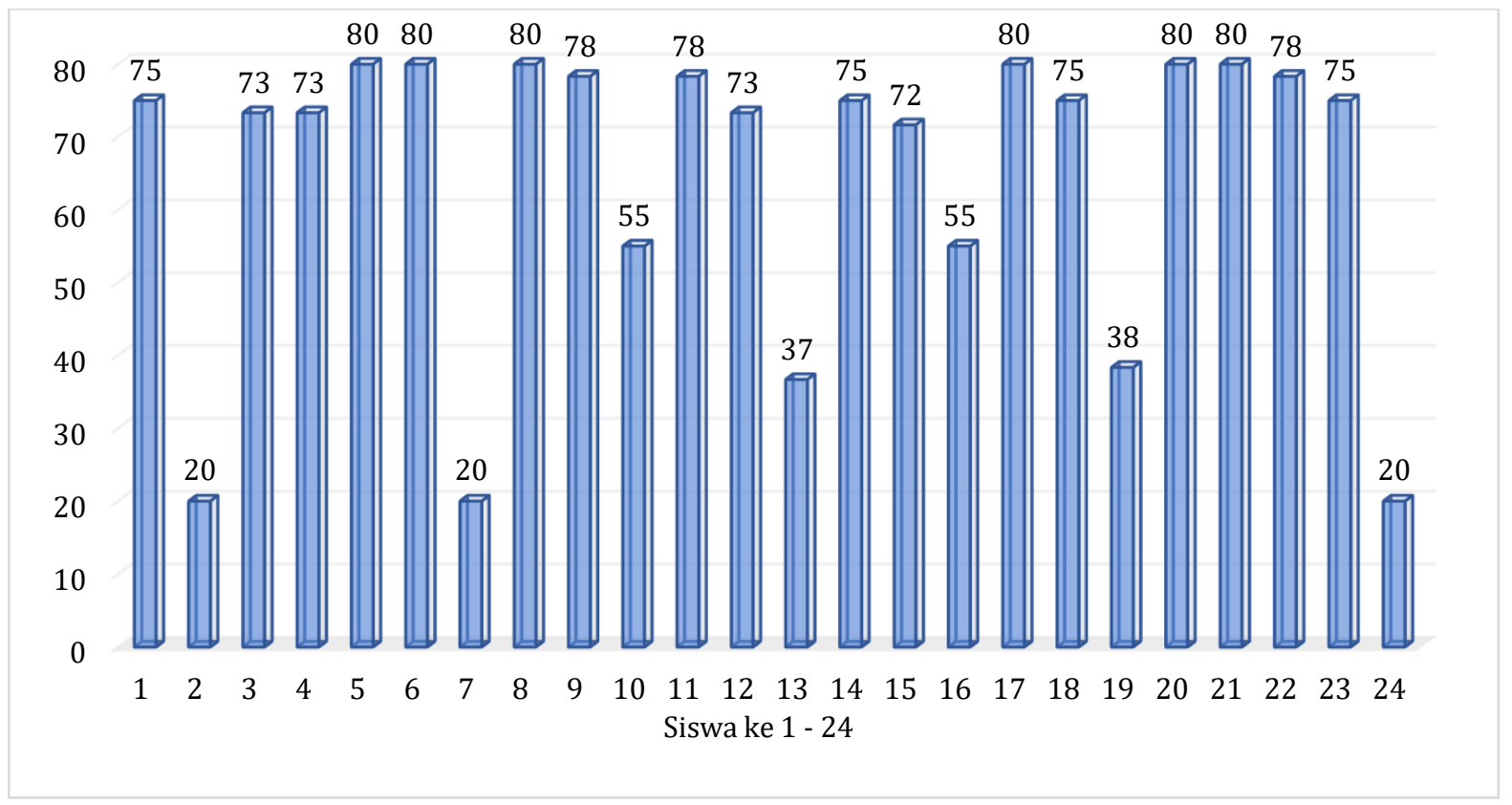

Gambar 5. Hasil pengukuran sikap siswa selama penerapan PjBL

PTK yang telah selesai dilaksanakan membuktikan bahwa PjBL mampu meningkatkan hasil belajar siswa. PjBL dapat mengubah pengajaran biologi menjadi lebih efektif. Walaupun capaian dalam kognitif, afektif dan psikomotorik tidak 100\%, tetapi ada perubahan pembelajaran biologi sebelum dan setelah penerapan PjBL. PjBL memberikan dampak positif terhadap hasil belajar (Lee, 2015).

Bagian penting dari P-BL adalah aktivitas kolaboratif antar siswa untuk melaksanakan tugas yang diberikan (Kaldi, Filippatou, \& Govaris, 2011). Kualitas proses kelompok untuk keberhasilan kolaborasi dalam PjBL (Cheng, Lam, \& Chan, 2008). Temuan Karaçalli dan Korur (2014) menunjukkan bahwa siswa belajar untuk membangun pembelajaran mereka sendiri dan mengevaluasi perubahan perilaku mereka sendiri melalui penerapan metode tersebut. Oleh karena itu, untuk meningkatkan konsepsi ilmiah siswa, guru harus membimbing dan mengontrol kolaborasi dan pengembangan siswa melalui proses pembelajaran berbasis proyek (Bell, 2010). Siswa dalam riset ini berkolaborasi menyelesaikan tugas proyek pembuatan media pembelajaran. Selain itu mereka juga mengerjakan kegiatan percobaan Bersama kelompok. Kegiatan inilah yang membuat mereka sukses dalam belajar. Kegiatan percobaan dilakukan di ruang kelas. Mengingat fasilitas laboratorium di sekolah yang ada di Papua masih belum lengkap fasilitasnya (Frabun, Iwan, \& Wambrauw, 2018).

Dalam PjBL terdapat proyek yang dikerjakan siswa. Proyek yang dikerjakan oleh siswa dan telah selesai kemudian siap untuk melakukan presentasi. Proyek yang dikerjakan dapat selesai tepat waktu sesuai rencana yang telah dijadwalkan, hal ini dapat memberikan pengalaman kepada siswa untuk mengerjakan tugas sesuai alokasi waktu yang ditentukan. Saat melakukan presentasi, terlihat beberapa siswa menyampaikan tanggapan mereka terhadap produk yang dihasilkan oleh temannya. Mereka 
berkomentar mengenai kekurangan yang terdapat pada produk temannya serta memberi masukan sebagai perbaikan. Dalam PjBl, produk yang dihasil dari kegiatan proyek di presentasikan kepada siswa lain untuk diberi tanggapan (Rati, Kusmaryatni, \& Rediani, 2017).

Kolaborasi adalah strategi instruksional yang penting, terutama digunakan dalam hubungannya dengan PjBL dengan hasil belajar (Lee \& Reigeluth, 2015). Dalam riset ini ditemukan bahwa adanya peningkatan capaian belajar siswa. Walaupun tidak mencapai $100 \%$, tetapi jumlah siswa yang tuntas telah memenuhi standar kriteria minimal yang ditetapkan sekolah. Menciptakan belajar yang kreatif dan kolaboratif (Xu \& Liu, 2010) melalui PjBL mengubah kognitif, sikap dan keterampilan siswa. Mengingat hal ini, terbukti bahwa PjBL memfasilitasi pertumbuhan siswa dalam memperoleh keterampilan tersebut (Musa, Mufti, Latiff, \& Amin, 2012). PjBL di kelas sains sekolah menengah adalah metode untuk merangsang sikap, keterlibatan, kepercayaan diri, dan pemahaman dalam mempelajari topik lingkungan (Basche, Genareo, Leshem, Kissell, \& Pauley, 2016). Riset ini mengungkap bahwa selain kognitif siswa, lebih dari $60 \%$ siswa telah mencapai keterampilan dan sikap yang baik. Beberapa siswa yang masih menunjukkan sikap dan keterampilan yang kurang akan menjadi perhatian di PTK atau riset lain di masa mendatang. PjBL telah menciptakan siswa aktif dan kolaboratif yang membuat capain belajar mereka menjadi lebih baik. Guru dapat menciptakan pembelajharan biologi yang efektif dibandingkan ketika dia tidak menggunakan PjBL dalam pembelajaran.

\section{Simpulan}

Berdasarkan hasil penelitian yang didapatkan bahwa hasil belajar siswa kontrol (konvensional) dan eksperimen (PBM) tidak menunjukkan perbedaan signifikan. Diperlukan beberapa inovasi untuk mengoptimalkan penerapan PBM dalam pembelajaran biologi, khususnya materi invertebrate.

\section{Referensi}

Al-Balushi, S. M., \& Al-Aamri, S. S. (2014). The effect of environmental science projects on students' environmental knowledge and science attitudes. International Research in Geographical and Environmental Education, 23(3), 213-227. https://doi.org/10.1080/10382046.2014.927167

Allison, P., Gray, S., Sproule, J., Nash, C., Martindale, R., \& Wang, J. (2015). Exploring contributions of project-based learning to health and wellbeing in secondary education. Improving Schools, 18(3), 207-220. https://doi.org/10.1177/1365480215599298

Bahtiar, W. A., Nunaki, J. H., \& Iwan, I. I. (2018). Development of Biology Interactive Learning Multimedia on Animal Tissue Topic in The Class XI IPA in SMA Yapis Manokwari. Inornatus: Biology Education Journal, 1(1), 42-58. https://doi.org/10.30862/inornatus.v1i1.26

Barak, M. (2012). From 'doing' to 'doing with learning': reflection on an effort to promote self-regulated learning in technological projects in high school. European Journal of Engineering Education, 37(1), 105-116. https://doi.org/10.1080/03043797.2012.658759

Barak, M., \& Asad, K. (2012). Teaching image-processing concepts in junior high school: boys' and girls' achievements and attitudes towards technology. Research in Science \& Technological Education, 30(1), 81-105. https://doi.org/10.1080/02635143.2012.656084

Basche, A., Genareo, V., Leshem, A., Kissell, A., \& Pauley, J. (2016). Engaging Middle School 
Students through Locally Focused Environmental Science Project-Based Learning. Natural Sciences Education, 45(1), 1-10. https://doi.org/10.4195/nse2016.05.0012

Bell, S. (2010). Project-Based Learning for the 21st Century: Skills for the Future. The Clearing House: A Journal of Educational Strategies, Issues and Ideas, 83(2), 39-43. https://doi.org/10.1080/00098650903505415

Cheng, R. W., Lam, S., \& Chan, J. C. (2008). When high achievers and low achievers work in the same group: The roles of group heterogeneity and processes in project-based learning. British Journal of Educational Psychology, 78(2), 205-221. https://doi.org/10.1348/000709907X218160

Damopolii, I., Yohanita, A. M., Nurhidaya, N., \& Murtijani, M. (2018). Meningkatkan keterampilan proses sains dan hasil belajar siswa melalui pembelajaran berbasis $\begin{array}{llll}\text { inkuiri. Jurnal } & \text { Bioedukatika, }\end{array}$ https://doi.org/10.26555/bioedukatika.v6i1.8029

Demirdöğen, B. (2016). Interaction Between Science Teaching Orientation and Pedagogical Content Knowledge Components. Journal of Science Teacher Education, 27(5), 495-532. https://doi.org/10.1007/s10972-016-9472-5

Ferguson, R. F., \& Danielson, C. (2015). How Framework for Teaching and Tripod 7Cs Evidence Distinguish Key Components of Effective Teaching. In T. J. Kane, K. A. Kerr, \& R. C. Pianta (Eds.), Designing Teacher Evaluation Systems (pp. 98-143). San Francisco: John Wiley \& Sons, Inc. https://doi.org/10.1002/9781119210856.ch4

Frabun, R. F., Iwan, I., \& Wambrauw, H. L. (2018). The effectiveness of laboratory use in supporting biology practicums in high schools throughout Manokwari Regency. Inornatus: Biology Education Journal, 1(1), 1-9. https://doi.org/10.30862/inornatus.v1i1.109

Kaldi, S., Filippatou, D., \& Govaris, C. (2011). Project-based learning in primary schools: effects on pupils' learning and attitudes. Education 3-13, 39(1), 35-47. https://doi.org/10.1080/03004270903179538

Karaçalli, S., \& Korur, F. (2014). The Effects of Project-Based Learning on Students' Academic Achievement, Attitude, and Retention of Knowledge: The Subject of "Electricity in Our Lives." School Science and Mathematics, 114(5), 224-235. https://doi.org/10.1111/ssm.12071

Kokotsaki, D., Menzies, V., \& Wiggins, A. (2016). Project-based learning: A review of the literature. Improving Schools, 19(3), 267-277. https://doi.org/10.1177/1365480216659733

Lee, D., H, Y., \& Reigeluth, C. M. (2015). Collaboration, intragroup conflict, and social skills in project-based learning. Instructional Science, 43(5), 561-590. https://doi.org/10.1007/s11251-015-9348-7

Lee, Y. M. (2015). Project-Based Learning Involving Sensory Panelists Improves Student Learning Outcomes. Journal of Food Science Education, 14(2), 60-65. https://doi.org/10.1111/1541-4329.12057

Musa, F., Mufti, N., Latiff, R. A., \& Amin, M. M. (2012). Project-based Learning (PjBL): Inculcating Soft Skills in 21st Century Workplace. Procedia - Social and Behavioral Sciences, 59, 565-573. https://doi.org/10.1016/j.sbspro.2012.09.315

O’Neill, S., Geoghegan, D., \& Petersen, S. (2013). Raising the pedagogical bar: Teachers' coconstruction of explicit teaching. Improving Schools, 16(2), 148-158. https://doi.org/10.1177/1365480213493709

Rati, N. W., Kusmaryatni, N., \& Rediani, N. (2017). Pengaruh model pembelajaran berbasis proyek terhadap kreativitas dan hasil belajar pendidikan IPA SD mahasiswa PGSD Undiksha UPP Singaraja. JPI (Jurnal Pendidikan Indonesia), 6(1), 60-71. 
https://doi.org/10.23887/jpi-undiksha.v6i1.9059

Samara, N., Yohanita, A. M., \& Iwan, I. (2018). Application of problem-solving learning models to improve the activity and students' learning outcomes of SMA Kristen YABT Manokwari. Inornatus: Biology Education Journal, 1(1), 30-41. https://doi.org/10.30862/inornatus.v1i1.38

Watem, M., Nunaki, J. H., \& Wambrauw, H. L. (2018). Profile of Infrastructure and Pedagogic Competencies of Teachers in SMP and SMA/SMK in Waisai District, Raja Ampat Regency, West Papua Province. Inornatus: Biology Education Journal, 1(1), 10-29. https://doi.org/10.30862/inornatus.v1i1.16

$\mathrm{Xu}, \mathrm{Y} .$, \& Liu, W. (2010). A project-based learning approach: a case study in China. Asia Pacific Education Review, 11(3), 363-370. https://doi.org/10.1007/s12564-0109093-1 